\title{
Cycle logistics: \\ The potential of cargo bicycle as a sustainable solution for urban logistics in Brazil
}

\author{
Victor ANDRADE, LABMOB UFRJ, Brazil \\ Marcela G. Q. KANITZ, LABMOB UFRJ, Brazil \\ Jéssica G. de LUCENA, LABMOB UFRJ, Brazil
}

\begin{abstract}
The transport of goods, particularly in dense urban areas, contributes to a problem that most of today's cities share: they are overcrowded by motorized traffic. In that context, urban freight and city logistics are central to the Brazilian economy, but face a number of economic and environmental challenges. This paper aims to contribute to a new body of research that investigates the potential of cycle couriers to make city logistics more sustainable and explores ways to encourage their diffusion. In the course of congested cities, increasing delivery volumes and growing environmental awareness, both local public administrations and logistics service providers are faced with the challenge of finding sustainable solutions for urban freight transport. The study analyses the dynamic of the development of cycle logistics in the Brazilian context from an economic, environmental and social perspective. In order to conduct the research, data collection methods were used, including: application of questionnaire and in-depth interview with bike courier companies and collecting secondary data from the Brazilian National Data Basis. Based on this national scale study (developed in 2020) we identify Brazilian bike courier companies and characterize business model, performance and workers profile. The results show the growth potential of bike courier businesses and that can be a suitable addition to urban consolidation concepts from both an environmental and financial point of view. The findings of the paper are of interest to policymakers, urban logistic operators, research institutions, and citizens as potential customers.
\end{abstract}

\section{Keywords}

Cyclelogistics, logistics, bicycle, mobility, urban planning

\section{Introduction}

Cyclelogistics activity uses bicycles or tricycles to carry out logistics activities (LABMOB and Aliança Bike, 2018). Within cycle logistics, the last mile delivery activity refers to the use of the bicycle as a means of transport for the delivery and distribution of goods or merchandise. This is the stage of transport logistics where most bicycle deliveries fit in and is considered one of the most expensive, inefficient, and polluting parts of the logistics chain (Gavaers et al., 2009).

Promoting cycle logistics is crucial to enhance delivery transportation in urban contexts facing significant traffic congestion and critical climate conditions. Several national and international studies and cases have already pointed out cycle logistics competitive advantages over other modes (Vijayakumar, 2017; Nascimento, 2019). Furthermore, bicycles have greater capillarity penetrating urban fabric because they take up less space on the streets than vans and trucks. Besides, parking a bike is vastly easier than parking 
a car at a destination. Thus, bicycles get many deliveries to come faster and at lower costs, in addition to reducing noise and air pollution and saving emissions.

Therefore, cycle logistics has gained ground in Brazil's market to prove an efficient and sustainable solution. Especially for last-mile logistics, traditionally carried out mainly by motorcycles and small trucks that are less energy-efficient modes of transportation.

In this context, this study aims to discriminate the activity of cycle logistics in Brazil, emphasizing the bike courier service. A comprehensive and systemic look at this activity collected information and data on the different actors involved: companies, delivery-cyclists, and client companies.

Following the present introduction, Section 2 briefly describes the methods and procedures used to collect all data analyzed. Then, section 3 brings forward discussion and results from mapping the bike courier service in Brazil's market and activities according to questionnaires and case studies. Finally, section 4 delivers conclusions and challenges found during the survey.

\section{Materials and methods}

This research sought to increase comprehensive evidence on the cycle logistics economy, focusing on the national bike courier service. To do so, methods employed various data collection instruments and triangulation of Quali Quanti data.

In Brazilian literature, there is still a lack of systematized knowledge regarding cycle logistics. So then, we conducted exploratory research to comprehend its sector. The exploratory analysis constitutes the first stage of a broader study. Therefore, it is a widely used method in research whose subject has been little explored. It can be applied in initial studies to obtain an overview of specific facts (Vergara, 2011).

An online survey was sent out to companies in order to let us georeference them considering the largest cities in each national macroregion. The following cities were considered: Manaus, Belém, Fortaleza, Recife, Salvador, Curitiba, Florianópolis, Porto Alegre, Belo Horizonte, Rio de Janeiro, São Paulo, Brasília, Campo Grande (Figure 1). This mapping attempted to distinguish the profile of Brazilian cycle logistics companies, services provided, advantages, and challenges, in addition to barriers and opportunities for boosting the sector's growth.

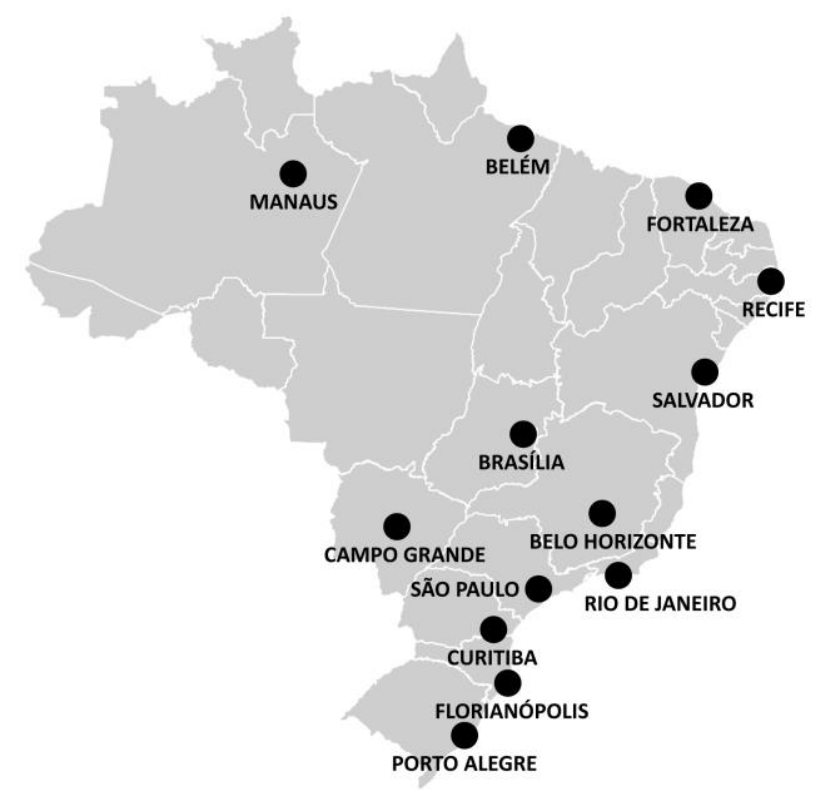

Figure 1. Brazilian cities considered for the survey. Source: Labmob 
The bike courier companies surveyed composed the sampling frame (Babbie, 2001) we selected to apply a second survey. The survey was built on a structured questionnaire that sought to investigate the profile of companies in the sector. Despite efforts to encompass the whole universe, this list might present limitations given the challenging fact of mapping such an under notified market in literature. Therefore, this study raised findings that can highlight business trends and peculiar features of cycle logistics.

The companies' primary data on their operations were collected and mapped through a voluntary response sample through the Survey Monkey@ platform. The questionnaires were completed between October 23, 2019, and January 24, 2020. The choice of variables included in the questionnaires was guided by their specific objectives, as indicated above.

Two case studies were also carried out. The first was with the company Carbono Zero Courier, a bike courier service provider in the city of São Paulo. We sought to obtain a more comprehensive understanding of the company's logistics and its service provided. As a result, detailed data were collected on the operation of Carbono Zero Courier, collected through in-depth interviews with the company's CEO and questionnaires voluntarily responded by the company's 165 delivery-cyclists.

Finally, a second case study was carried out with four bike courier service clients from different sectors. In-depth interviews with strategic representatives of these bike courier business clients were conducted to learn about their perceptions and opinions on hiring professional bicycle delivery.

\section{Results and Discussion}

\subsection{Bike Courier Company Profile}

In 2019, 39 Brazilian bike courier companies were identified in operation. Companies were asked to fill in questions about their employees, delivery travel behavior, and types of goods delivered. In the end, 24 companies voluntarily responded to the questionnaire made available online. These companies mainly appeared between 2010 and 2015, 62\% of the total responding companies. Despite the context of the beginning of the political-economic crisis in Brazil in 2014, 23\% of companies (9 out of 39) opened in 2015. About 25\% (10 out of 39) were established after that year. The southeast region of Brazil concentrates around $60 \%$ of the companies mapped, followed by the south region (20\%), the northeast region (9\%), the central-west region (8\%), and, finally, the north region (5\%).

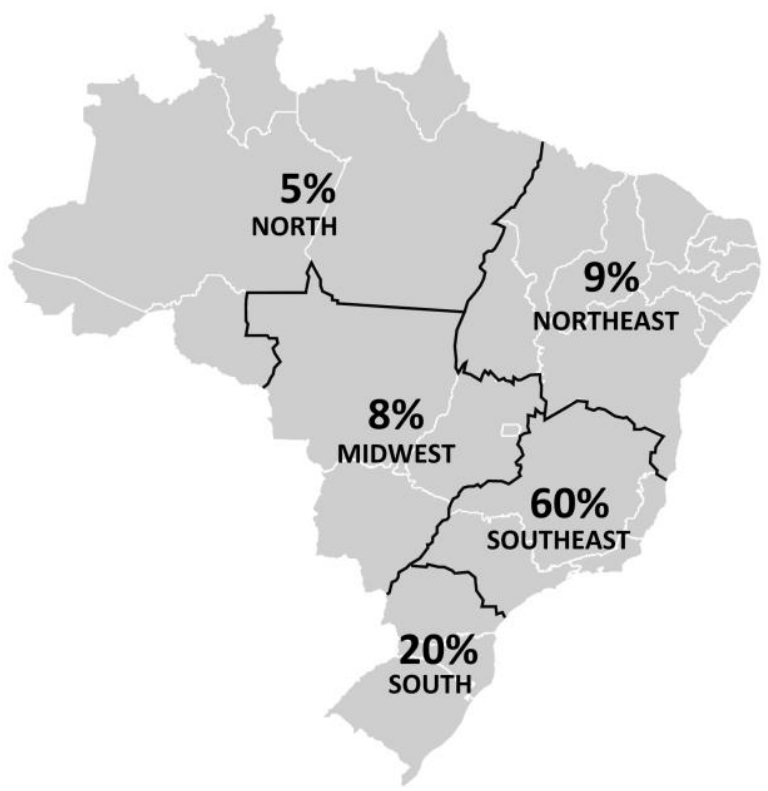

Figure 2. Companies distribution per region. Source: LABMOB. 
Respondent companies mostly hire a small workforce of up to 10 delivery cyclists, representing $77 \%$ of the total companies (Figure 3 ). It is essential to point out that only $8 \%$ of companies operate with fleets over 50 bicycles. It was also found that there are companies with fleets exceeding 100 bikes. Even though findings show a diversity of medium-sized companies, small companies still prevail in the market. Consequently, most of them face challenges in attending to potential customers as they cannot handle the high delivery demands.

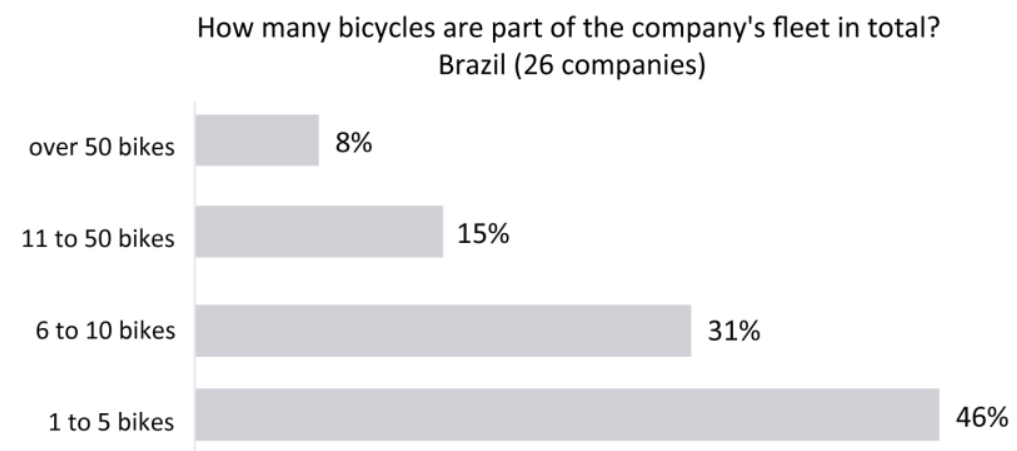

Figure 3. Brazil: delivery bicycles fleet. Source: LABMOB and Aliança Bike, 2020

Another crucial aspect regarding companies' capacity is owning or not a fleet. More than half of the companies ( $58 \%$ out of the total) indicated that delivery cyclists own the bikes they ride. Thus, the company did not have any bicycles of its own. In contrast, $12 \%$ of companies indicated they own the entire bicycle fleet. It is worth mentioning that bicycle fleet presents an initially high total cost of ownership. Added to this cost is the provision of infrastructure to allocate them - from space to park unused vehicles to a team responsible for monitoring operationalizing the fleet. In addition, the bicycle fleet is an asset that becomes depreciated over time. Therefore, it turns into a long-term problem as modernizing the fleet makes companies run higher expenses to keep them in shape.

On the other hand, $31 \%$ of companies registered to run a hybrid model business: mix both worker's private bikes and company's vehicles. A hybrid model innovates as enabling the companies to grow through greater flexibility by sharing operational costs. Besides, a hybrid-fleet composition also makes it possible to allocate resources efficiently on demand. For example, if demand for deliveries increases, it is possible to expand the fleet into partnerships with cyclists using private bicycles. It does not require greater investment in acquiring assets. On the other hand, if the demand for deliveries decreases, the company is released from costs to keep bicycles inactive and depreciating.

\subsection{Profile of Delivery Cyclists}

The company's workforce is made up of delivery cyclists who ride mainly on conventional bicycles with the support of accessories for transporting loads (Figure 4). The use of electric bikes is very unsatisfactory. Half of the responding companies hold a small group of deliverers, with up to five riders on their team. Cyclists work mainly as freelancers. Some of them are hired as legal, individual microentrepreneurs. In Brazil, an individual entrepreneur is a businessperson who works for his own account and legally registers himself. About two-thirds of the companies declared offering any training for all the delivery cyclists that join their team. 
How many bicycles are part of the company's fleet in total?

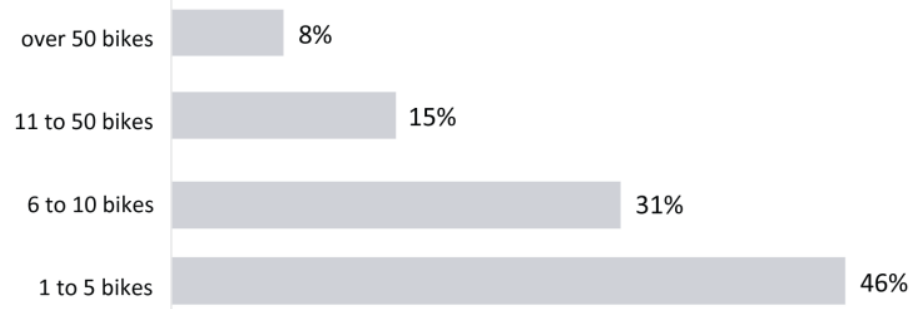

Figure 4. Type of bicycles that make up companies' fleet. Source: LABMOB and Aliança Bike, 2020

Two-thirds of delivery cyclists have been working in the business for up to a year. Their motivations are because they enjoyed cycling and the sense of freedom given from not having a work routine that the service provides. Most cyclists (90\%) already used the bicycle to commute before working with deliveries. About $60 \%$ had used the bicycle as a mode of commuting for more than five years, $21 \%$ between two and five years, $12 \%$ between one and two years, and $7 \%$ between six months and one year.

Concerning accidents, collisions, or runovers, $60 \%$ of respondents have already been involved in some type of disaster. Among these, $45 \%$ needed hospital care on some of these occasions. Delivery cyclists were also asked about the habit of wearing a helmet, which is mandatory during worktime. The vast majority, $91 \%$, declared using it whenever they ride. The remaining $9 \%$ only when they are within working hours.

The vast majority of respondents (91\%) said they noticed some improvement in their health and wellbeing after working in the sector. When asked about the main perceived health improvements, the increase in fitness and fitness (30\%) stands out. With ranges between $10 \%$ and $20 \%$, they appear as benefits: weight loss, physical and emotional well-being, and stress reduction. Respondents also mentioned the perception of reduced daily fatigue.

\subsection{Delivery Travel Behaviour}

As shown in Figure 5, the average distance of a bicycle delivery trip in companies concentrates in the range between 3 and 10 kilometers, corresponding to $62 \%$ of the total. The results also show that $8 \%$ of the companies hold an average distance above 20 kilometers. The average length of another $8 \%$ is below 1 kilometer.

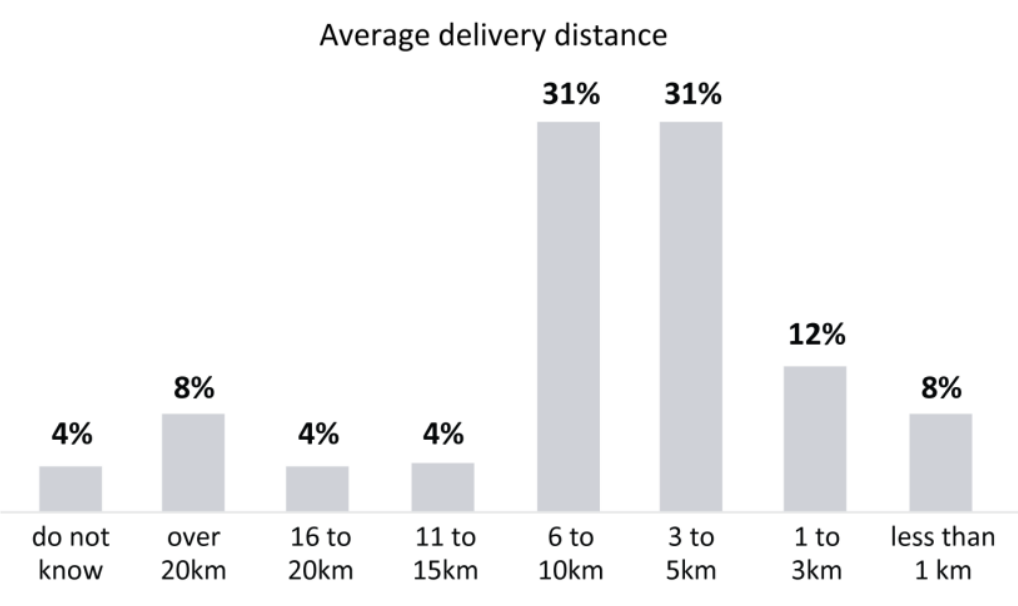

Figure 5. Average delivery distance. Source: LABMOB and Aliança Bike, 2020. 
Around $90 \%$ stated that, on average, they make up to 50 deliveries per day (Figure 6). The average number of daily deliveries was 22 , not considering companies that declared 1,000 or more deliveries. Therefore, they were out of the comparison scale with the others.

Average number of deliveries

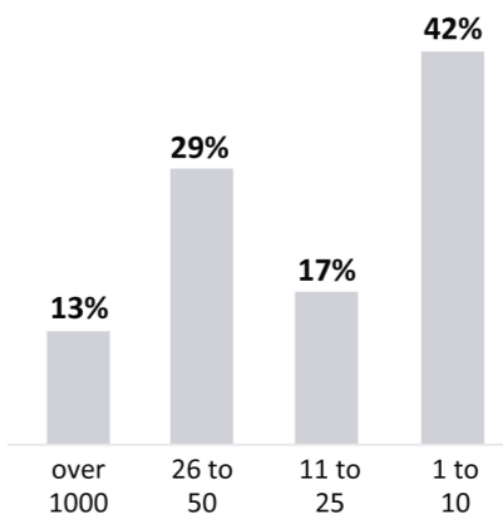

Figure 6. The average number of deliveries

\subsection{Types of Delivered Products and Main Customers}

Regarding which types of products they load, document deliveries \& personal services are the most common services carried out by cycling (Figure 7). In the field of "others," companies declared delivering flowers, cards, and small devices or equipment. None of the companies claimed to make only one specific type of delivery. Most of the transported loads weigh between 500 grams and 1 kilogram. Only five companies declared that they carry products above 5 kilograms mostly.

What types of bicycle delivery does your company carry out?

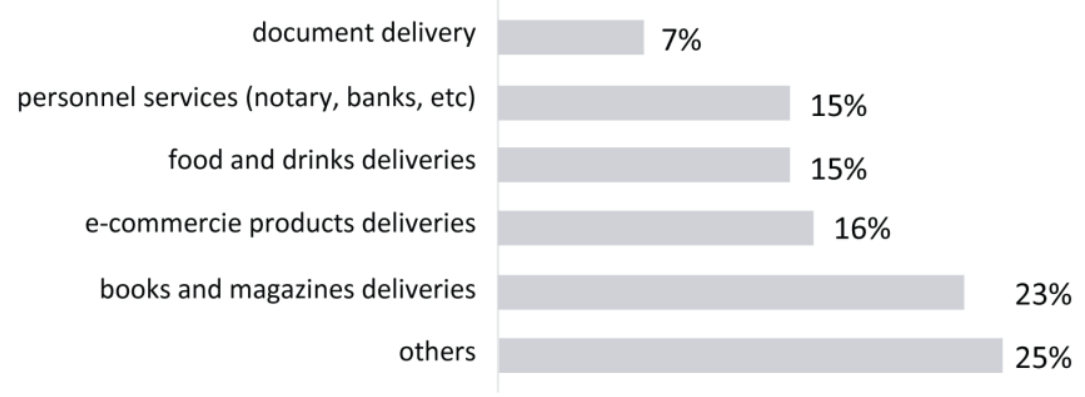

Figure 7. Type of delivery made. Source: LABMOB and Aliança Bike, 2020

Therefore, bike courier companies surveyed deliver various products: documents, electronics, clothing, books, magazines, shoes, cosmetics, cleaning products, beverages, cigarettes, food, and even laboratory test sample. In addition, several products were indicated in the "others" range, especially cyclists working with customers from the e-commerce sector. Finally, the companies told that their main customers are "offices and companies in general," "e-commerce companies," "commercial establishments in general," and "restaurants and food-related companies."

\subsection{Types of bicycles}

Regarding the bicycles used for deliveries, 25 of the 26 companies own conventional (urban) bikes. And

P ISP $57^{\text {th }}$ ISOCARP World Planning Congress 8-11 November 2021 | Doha, Qatar 
more than half ( 16 of the 26 respondents) declared using only these models. Of the seven companies that said they also use cargo bicycles, five are in São Paulo, and all three also use electric bikes.

Due to the lack of diversity in the bicycles used, the couriers use accessories to uphold transport cargo (Figure 8). The backpack and the rear luggage compartment were pointed out as the most common accessories by cyclists, followed by baskets and, to a lesser extent, messenger bags. Accessories such as saddlebags, bicycle front loaders, and even plastic bags tied to the backpacks help increase the carrying capacity, as they mentioned. Other types of bicycles, such as cargo models, would facilitate working dynamics every day.

What type of acessories do you use to transport products / cargo ?

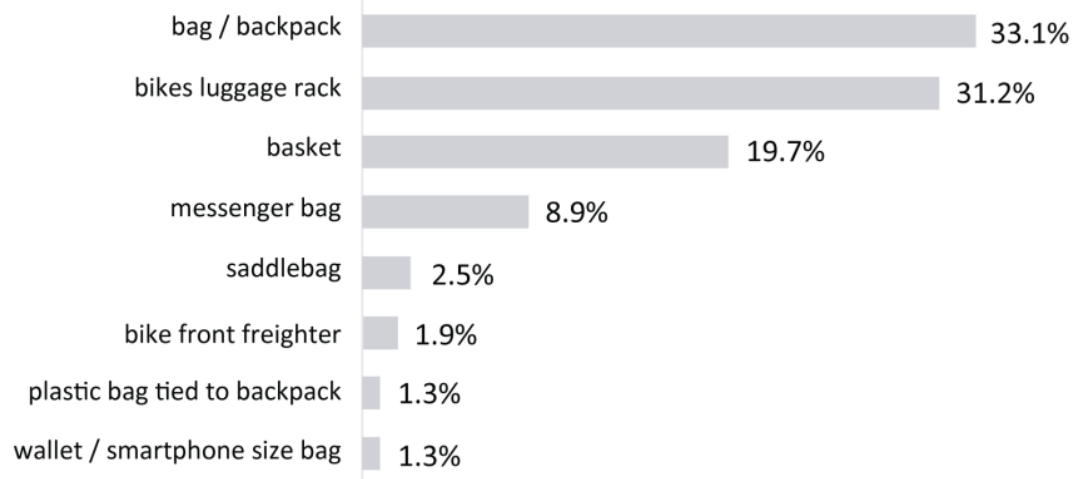

Figure 8. Accessories Several products were indicated used to transport cargo/products. Source: LABMOB and Aliança Bike, 2020

A challenge identified among the models of electric bicycles available for sale in Brazil is that most are developed for recreational purposes and not for delivery services. So, they need to be readjusted for this goal. In general, the electric bicycle market faces substantial challenges nationwide. Opposing the evolution of the national market for electric bicycles is the taxation on Industrialized Products (IPI, Imposto sobre Produtos Industrializados). Rates on electric bicycles are among the highest in Brazil and exceed those applied to products such as cars, even alcoholic beverages, and tobacco items (ALIANÇA BIKE, 2020). This barrier in accessing electric bicycles, especially cargo models, hinders the progress of cycle logistics in the country.

\subsection{Successful case study. The largest Brazilian bike courier company: Carbono Zero}

In October 2019, the company claimed to hold a fleet made up of 165 delivery cyclists and make around 3,000 daily deliveries. Carbono Zero offers flexible and differentiated service models according to the specific demands of each type of customer. It can serve from an individual with a single delivery order to another small, medium, or large company that requires a team of exclusive cyclists to operate their logistics demand.

Also, in 2019, the company had four types of product-storage hubs that served to support delivering among the company's cyclists. Except for the company's headquarters, these locations are primarily used for providing e-commerce products, serving as a storage and distribution point for the products by cyclists. Deliveries are routed by operators in the smartest, efficient way - whenever possible, centralizing deliveries in a range close to the same cyclist's physical location. According to company interviewees, lockers are the most promising types of storage for boosting cycle logistics.

Customers can follow the entire delivery process from point A to point B through a real-time website, identifying in real-time information of the Service Order. They can also collect digital receipt signatures. 
The website is connected to a smart-based logistic operation system developed specifically for the company.

The company's fleet consists of bicycles used by the hired employees and bicycles belonging to the freelance cyclists themselves. All the company's cyclists go through a training process, whether they are formally hired or freelancers.

From 2017 to 2019, the company was able to increase its turnover and size considerably. This growth allowed the service to improve, growing cyclists, operators, and managing teams. According to the interviewees, during this period, no significant marketing actions were carried out. The main reason for this growth was the organization and structuring of the company, which increased its effectiveness and efficiency, allowing the expansion of services to more prominent e-commerce companies. At the moment, the company focuses on fixed-based deals with other companies for sporadic delivery services.

Carbono Zero Courier recognizes efficiency in dense and congested urban centers as the two main advantages of bicycle delivery. The company also brings out the environmental issues, as bikes do not emit GHGs or generate noise pollution for cities when in motion. Regarding the limitations of the types of products delivered by the bike courier service, only restrictions related to weight, volume, and value were mentioned. Weight and volume refer to the load capacity limitations inherent in the vehicles themselves and the cyclist's ability to carry large, heavy goods. The lack of availability of cyclists was mentioned as one of the limitations to increasing its fleet, which already sees a greater demand than its network can offer.

Most of the fleet used by the company's delivery cyclists analyzed in the Carbon Zero Courier case study comprises 26-inch conventional bicycles rims. However, the company also has five electric cargo bikes (Long John model) and uses electric bikes in a small number. The cargo bike has a capacity of up to 100 kilograms. It is handled primarily to carry heavier loads such as beverages and cleaning products. In addition to bicycles, the company's fleet also holds 12 electric scooters and 2 electric vans to support the operation.

\subsection{Learning from Bike Courier service client companies}

Four companies from different sectors were selected for a qualitative analysis on motivations to hire a bike courier service of different scales, delivering 50 daily deliveries, reaching more than 1,000 in some cases They were: Natura (cosmetics), Nextel (telecommunications), Positiva (natural cleaning products), and a sizeable Brazilian e-commerce company that preferred no identifying. Their primary common motivation is to promote sustainability through deliveries. In addition, four companies stated that they are interested in increasing the sharing of bikes in their logistics.

The in-depth interviews showed that the main motivation common to all companies is promoting the sustainability of deliveries provided by bicycles. In addition, the four companies stated that they are interested in expanding the participation of bikes in their logistics.

For Nextel, the environmental issue (the sustainability of deliveries by bicycle) is the central differential and the primary motivation for hiring the bike courier service from this company's point of view. In addition, the company seeks to know the mileage traveled by each of the delivery cyclists to estimate the emissions avoided by its fleet. If more delivery cyclists got into the market, allowing turnover to increase cost-benefit, Nextel's representative said the company would amplify the share of bicycles in their logistics.

The e-commerce company registered interest in increasing the share of bicycles in its urban logistics. It is also studying to expand its market. In addition, the representative interviewed suggested some 
improvements to encourage boosting the sector. Among them, improving urban cycling infrastructure, expanding bike lanes (to improve deliverer's safety), and route options deliveries.

\subsection{Challenges for the Cycling Sector's Growth in Brazil}

The bike courier companies pointed out several challenges for the sector to grow. However, as the critical challenge and the lack of knowledge of the public sector and potential customers, the bicycle is an adequate transport alternative for last-mile logistics.

This issue is reflected in the public sector's lack of hiring cycle logistics services and public sector investments in road infrastructure (such as cycle paths, cycle lanes, paracycles, and bicycle racks) to support the activity and trips by bicycle in general. In addition, there is a range of potential clients from the private sector who are unaware of cycle logistics. Consequently, most Brazilian companies still only hire motorcyclists and mini trucks for last-mile delivery services.

This scenario indicates the urgency of establishing public policies to encourage and promote cycle logistics, which is an activity that benefits businesses and cities, increasing the quality of urban life.

On the other hand, the interviewed customers indicated criticism of expanding cycle logistics activity. The reasons for the difficulties in delivering bicycles, obtaining insurance, documents, and permissions from the different regulatory bodies and public agencies related to cargo transport were their judgments. This point reinforces the need for the Public Power to institute public policies to promote cycle logistics.

Finally, the cyclist delivery people interviewed indicated two main problems in their daily work. First, the lack of a stopping place or bicycle rack at the destination of deliveries. The second challenge is the weather conditions limiting delivery capacity under severe climate conditions such as tropical rains, making deliveries more time-consuming and eventually impracticable.

\section{Conclusions}

Bicycle delivery is an efficient alternative for urban freight in economic, social, and environmental aspects. Cyclologistics presents the bicycle as a modal alternative capable of generating greater efficiency and flexibility to different business models. As a result, it has found more and more space in the Brazilian market. The data presented sought to increase understanding of issues on cycling deliveries related. And also inform the public, private and civil society sectors with data on the profile of companies to support future decision-making.

From an economic point of view, the bicycle is a vehicle that generates fewer maintenance costs than motor vehicles, which depend primarily on fossil fuels in Brazil. This fact generates more significant savings for both autonomous couriers and bicycle delivery companies. Besides, our findings are that the cycle logistics market goes through a fast-growing process to share participation in the market. Companies declared to be optimistic about their expectations for growth in the coming years, despite acknowledging competitiveness with traditional modes.

Cyclologistics provide solutions to problems of incomplete delivery due to urban traffic problems and difficulty in parking. They are, therefore, a solution to be adopted by companies seeking to make their logistics more accurate and with a sustainable bias.

The attention that has been given to the environmental matter and the conditions of greater permeability in the urban network are differentials for deliveries by bicycle. Especially for the last mile and compared to the logistics carried out predominantly by motor vehicles, such as vans, trucks, and motorcycles. 
In addition to the growth of cycle logistics companies and the increase in the economic sustainability of this business model, cycle logistics brings positive impacts to cities by improving air quality, reducing noise pollution, and avoiding the emission of greenhouse gases.

Because of the benefits to society of the logistic cycle activity, it is essential to develop public policies that promote cycling deliveries. These policies range from regulatory actions and tax incentive policies to providing adequate cycling infrastructure in urban areas.

\section{References}

ALIANÇA BIKE (2020). 'Potência, energia e renovação: a vez das bicicletas elétricas'. Revista Bicicletas Elétricas. [online] Available at: https://aliancabike.org.br/wp-content/uploads/docs/2020/09/RevistaBicicletas-Eletricas.pdf (Accessed: 15 Aug. 2021)

ALIANÇA BIKE and LABMOB (2018) Ciclologística; entregas de bicicleta e triciclo no Bom Retiro. Relatório. São Paulo.

ALIANÇA BIKE and LABMOB (2020) Teste de modelos de bicicletas elétricas cargueiras para uso dos Correios - Praia Grande (SP). Brasília: PROMOB-E. [online] Available at: http://www.promobe.com.br/library/teste-de-modelos-de-bicicletas-eletrica-cargueiras-para-uso-doscorreiospraia-grande-sp/ (Accessed: 21 Sep. 2020)

BABBIE, E. (2001) Métodos de Pesquisa Survey. Belo Horizonte: UFMG.

BERNARDES, F. F.; FERREIRA, W. R. (2015) Logística urbana: análises e considerações acerca do transporte de cargas. Anais do 20 Congresso Brasileiro de Transporte e Trânsito. Santos: ANTP.

COMI, A. and SAVCHENKO, L. (2021) 'Last-mile delivering: Analysis of environment-friendly transport'. Sustainable Cities and Society. 74. [online] DOI: 103213. 10.1016/j.scs.2021.103213. (Accessed: 23 Mar. 2021)

CONFEDERAÇÃO NACIONAL DE TRANSPORTES (2018) 'Estudo revela dificuldades do transporte de cargas em centros urbanos', Agência CNT Transporte Atual [online]. Available at: https://cnt.org.br/agenciacnt/estudo-cnt-revela-dificuldades-transporte-cargas-centros-urbanos (Accessed: 8 Aug. 2021)

COX, P.; RZEWNICKI, R. (2015) 'Cargo bikes: Distributing consumer goods' in COX, P. (Eds.). Cycling cultures. 1. ed. Chester: University of Chester Press, p. 130- 151.

CYCLELOGISTICS (2019) Bicicletas cargueiras: um guia para prefeitas e prefeitos. Report [online] Available at: http://transporteativo.org.br/cargo/guia_prefeitura.pdf (Accessed: 30 May 2021)

GAVAERS, R., VAN DE VOORDE, E. and VANELSLANDER, T. (2009) Characteristics of innovations in last mile logistics - Using best practices, case studies and making the link with green and sustainable logistics. Association for European Transport and Contributors, p. 1-21.

LABMOB and ALIANÇA BIKE (2020) Ciclologística Brasil - Relatório Técnico (Report) Available at: https://www.labmob.org/ciclologistica-brasil (Accessed: 10 May 2021)

MAES, J.; VANELSLANDER, T. (2012) 'The use of bicycle messengers in the logistics chain, concepts further revised'. Procedia-Social and Behavioral Sciences, v. 39, pp. 409-423.

MARCHESINI, M. M. P., ALCÂNTARA, R. L. C. (2012) 'Conceituando o serviço logístico e seus elementos'. Revista Ciência \& Tecnologia, v.17, n. 33, pp. 65-68.

MOURA, B. C. (2006) Logística: Conceitos e Tendências. Lisboa: Centro Atlântico. 
NASCIMENTO, C. O. L. (2019) Análise do potencial da bicicleta para a distribuição urbana de mercadorias. Dissertation. Belo Horizonte: Universidade Federal de Minas Gerais. Available at: http://hdl.handle.net/1843/34654 (Accessed: 05 Aug. 2021)

NASCIMENTO, C., RIGATTO, I. B. and OLIVEIRA, L. (2020). 'Characterization and analysis of the economic viability of cycle logistics transport in Brazil'. Transportation Research Procedia. 46. DOI: 189-196. 10.1016/j.trpro.2020.03.180.

NUNES, A. M. L. (2017) Utilização de bicicleta cargueira no comércio varejista: Estudo de caso em cidade de porte médio. Thesis. Guaratinguetá: Universidade Estadual Paulista, UNESP. Available at: https://repositorio.unesp.br/bitstream/handle/11449/151763/nunes_aml_dr_guara.pdf;jsessionid=72C9 622CAE3255760F624CB299FF1415?sequence=3 (Accessed: 08 Aug. 2021)

OLIVEIRA, L. K. et al. (2018) Distribuição urbana de mercadorias e planos de mobilidade de carga: Oportunidades para municípios brasileiros. Brasília: Banco Interamericano de Desenvolvimento - BID. Available at: $10.18235 / 0001169$

PORTUGAL, F. C. A. (2007) Influência da Legislação no Transporte Urbano de Carga na Cidade do Rio de Janeiro. Dissertation. Rio de Janeiro: Coppe, Universidade Federal do Rio de Janeiro. Available at: https://www.livrosgratis.com.br/ler-livro-online-3055/a-influencia-da-legislacao-no-transporte-urbanode-carga-na-cidade-do-rio-de-janeiro (Accessed: 08 Aug. 2021)

SWENNEN, B.; RZEWNICKI, R. (2015) Recommendations on cyclelogistics for cities. European Cyclists Federation. [online] Available at: https://ecf.com/sites/ecf.com/files/CYCLE\%20LOGISTIC\%20internet.compressed.pdf (Accessed: 26 Nov. 2020)

VIJAYAKUMAR, N. (2017) Cyclelogistics: Opportunities for moving goods by bicycle in Toronto. Pembina Institute: Calgary. [online] Available at: https://www.pembina.org/reports/cyclogistics-final.pdf (Accessed: 15 Aug. 2021)

WRIGHTON, S. and REITER, K. (2016) 'CycleLogistics - Moving Europe Forward!'. Transportation Research Procedia. v. 12, pp. 950-958. Available at: 10.1016/j.trpro.2016.02.046. 